TITLE:

\title{
Essential Limitations and T-Nt Diagram for Self-sustaining Fusion Systems(Abstract_要旨)
}

\author{
AUTHOR(S): \\ Imoto, Mitsuo
}

\section{CITATION:}

Imoto, Mitsuo. Essential Limitations and T-Nt Diagram for Self-sustaining Fusion Systems. 京都大学, 1959, 理学博士

ISSUE DATE:

1959-03-23

URL:

http://hdl.handle.net/2433/210645

RIGHT: 


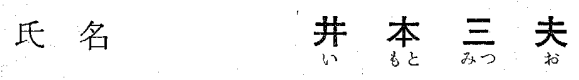

学位の種類、理学博士

学位記番号理博第 8 号

学位授与の日付 昭和 34 年 3 月 23 日

学位授与の要件、理学研究科物理学専攻・博士課程修了者

(学位規則第 5 条第 1 項該当)

学位論文 題目 $\quad \begin{aligned} & \text { Essential Limitations and T-Nt Diagram for } \\ & \text { Self-sustaining Fusion Systems }\end{aligned}$

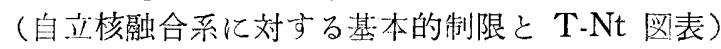

(住查)

論文調查委員教授湯川秀樹教授小林稔教授林忠四郎

\section{論 文 内 容 の 要 旨}

高温プラズマの制御された熱核融合反応系に扑いては，核反尤によるェネルギ一生成があっても，諸種

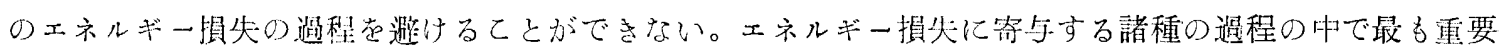
なのは，爾子とイオンの衝突に上る制動輻射の放出過程である。天体の場合は别にして，地上の規模の装

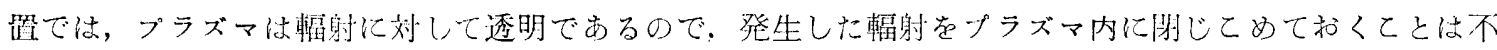
可能である。さらに，核反心のエネルギーは，生成核の運動エネルギーとして放出されるが，とくに，中 性子はプラズマを自由に通過して系外に逸脱するので，放出ェネルギーの一部が，プラズ、自身の加热に 用いられるにずざい。てれらの損失エネルギーをプラズマの外部で捕据して，再びプラズマに注入する ととによりとの冷却を防ぐにしても，ある值以上の効率をもっててれを行なうととはできない。したがっ て，実用的なェネルギー源としての自立核融合系の作動が可能なためには，上述の効率岩考虑して，核反 応のエネルギ一生成量が損失量を十分上廻るととが必要である。J. D. Lawson は，D－D 反応と D - T 反忍の三つの発熱的核融合反心夌エネルギー生成の基本過程とする系について，エネルギー利用に必要な

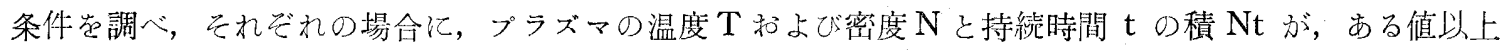
に大でなければならないととを見出した。温度と持続時間の二つの因子は，高温プラボマの制御可能性を 左右するものとして，現在，各国に打ける高温プラボマ研究の目標となっている。

Lawsonの条件は，核融合反応が進行しても，プラズマの組成が変化しないという仮定，㧍よび，電子 閪相互の衝突による制動輻射が無視できるという仮定のもとに䀠かれたものである。

井本三夫は，乙の種の非現実的な仮定芭除いた場合，またさらに，放出エネルギーの種類によってその 再利用の効率を区別した場合に，条件がどう変化するが詳しく検討した。まず，燃料が純重水素の場合 ( D - D 燃料) と, 重水素と三重水素とが等量混合している場合 ( D - T 燃料)の二つ炎選び，各温度につ いて，熱核反忘にょるプラズマ内の $\mathrm{D}^{2}, \mathrm{~T}^{3}, \mathrm{He}^{4}$ の濃度の時間的変化を数值積分によって求め，各時刻 に和けるエネルギ一生成量と損失量と茬計算した。ての際，衝突と核反応はともに二体の反応であるから， 反応の進行度は Nt (換算時間)で記述される。ついで, これらの数值芭用いて，エネルギ一利用が可能な 
$\mathrm{T}$ と $\mathrm{Nt}$ の領域を, 再利用効率として各種の值を仮定した場合について求めたのである。

その結果によると，D－T燃料の場合は，T - Nt 図上にエネルギ一利用の条件をみたす有限領域が存在 するととが示された。温度に上限があるのは，高温度においては制限輻射による損失がェネルギ一生成を 超すためであり，時間の上限はヘヘッムの蓄積による制動輻射の增加と燃料の減少のためである。D-D 燃料の場合には，放出される中性子のエネルギーの特別な利用法を考えない限り，上述の条件をみたす領 域が存在しないという，重要な結論が導かれた。核然料としての三重水素は自然に存在しない高価なるの であるから，核融合のエネルギ一利用の具体的方針を確立するためには，中性子を再利用する效摔のよい 方法を見出さねばならないのである。

以上に述べたように，主論文は，今後の核融合研究を進めてりくための基礎的な資料として，重要な意 味をもつものと思われる。

\section{論文審查の結果の要旨}

主論文は, 制御された核融合系反応によるエネルギ一利用の条件を，原子核反応理論とプラズマ理論と を用いて，詳細に分析したものである。てれまで，ての種の条件は，核反応の進行にともなう系の組成の 变化を無視した近以のもとに求められていた。

共本三夫は，反忘生成物の蓄積が輻射損失を增大させるとと，また，高温度では電子一電子衝突に上 る制動輻射の発生が無視でさるいとと考慮に入れて，䈣密かつ一般的なエネルギ一利用の条件を求め，

この条件は，系の温度と反応の換算持緢時間が適当な範囲内の值をもつとさに限り満足されるととを示し た。とくに，純重水素を燃料とする場合には，放出される中性子の特別な利用法を見出さない限り，条件 は満足されないととを示した。この研究成果は，プラズマの加熱揖よで保持の方法の選定などに関して， 今後の核融合研究の指針を与光るものとして，研究の発展に寄与するとてろが大である。

参考論文のその一(注1) とその四(注2)は, 水素学消費し尽くした星の内部に打いて, へリウム核相互の 融合反応によって C， O , Ne が生成される過程を理論的に検討し，その星の棈造と進化に及に゙す影響を 調べるとともに，生成される元素の存在比求めたものである。

井本三夫が, その共同研究者と協力して, 着実な研究態度のもとに, 複雑な閣題を如何に処理したかを 示す，興味ある論文である。

参考論文のその二(注3)，その三(注4) は，主論文の先躯となったもので，制御された核融合系に扔ける 反応の進行度は密度と時間の皘である換算時間で記述されること，また，反応生成核の内には一般に不燃 性のもののほかに，三重水素のような有効な燃料が含まれることを最初に明らかにしたものである。

参考論文との五(注5)は，星の内部に抢ける水素と他の元素の融合反応の反応率采系続的にしらへ，C-N 循環反応のほかに, $\mathrm{Ne}-\mathrm{Na}, \mathrm{Si}-\mathrm{P}, \mathrm{S}-\mathrm{Cl}$ の諸循環反心が可能なととを示し, その反応時間を求めたも のである。

要するに，井本三夫は，参考論文が示すように，その着実な研究態度によって，天体核現象ならびにブ ラズマ現象の理論の展開に重要な寄与をなした。とくに，その主論文は，熱核融合研究の基礎となるへき エネルギ一利用の条件を明確にしたものであって, 今後の, 核ェネルギ一利用の進展に寄与するとてろが 少なくない。よって，本論文は理学博士の学位論文として洒值あるものと認する。 
〔主論文公表誌名〕

Journal of Nuclear Energy, Part C. (創刊号予定)

〔参考論 文〕

注 1. Helium Capturing Reaction in Stars （天体に扔けるへリウム捕獲過程）

共著者 林 忠四郎. 早川幸男·菊池 健

Progress of Theoretical Physics, Vol. 16 ( 1956 ), No. 5.

注 2. 天体に扮け当 $\mathrm{He}^{4}$ 捕獾過程

共著者 林 忠四郎・早川幸男・菊池 健

素粒子論砄究 第 9 卷 (昭. 30 ) 第 5 号

注 3. On the Time-Variation in the Thermonuclear-Fusion Systems

(熟核融合系の時間变分について)

共著者 滕井三朗・富永五郎

Progress of Theoretical Physics, Vol. 21 (1959), No. 5.

注 4. T-Nt Diagram for Fusion Researches (熱核融合䂺究からの T- Nt 図表)

共著者 藤井三朗・富永五郎

Progress Theoretical Physics, Vol. 21 (1959), No. 6. (予它)

注５. サイクリックな熱核反応 I

共著者 〜 小川 潔・山口嘉夫

素粒子論研究 第 14 卷 (昭. 32 ) 第 3 号 
$\infty$ 医学 博士 